\title{
Questionnaire survey on factors influencing comfort with indoor environmental quality in Danish housing
}

Frontczak, Monika Joanna; Andersen, Rune Vinther; Wargocki, Pawel

Published in:

Building and Environment

Link to article, DOI:

10.1016/j.buildenv.2011.10.012

Publication date:

2012

Link back to DTU Orbit

\section{Citation (APA):}

Frontczak, M. J., Andersen, R. V., \& Wargocki, P. (2012). Questionnaire survey on factors influencing comfort with indoor environmental quality in Danish housing. Building and Environment, 50, 56-64.

https://doi.org/10.1016/j.buildenv.2011.10.012

\section{General rights}

Copyright and moral rights for the publications made accessible in the public portal are retained by the authors and/or other copyright owners and it is a condition of accessing publications that users recognise and abide by the legal requirements associated with these rights.

- Users may download and print one copy of any publication from the public portal for the purpose of private study or research.

- You may not further distribute the material or use it for any profit-making activity or commercial gain

- You may freely distribute the URL identifying the publication in the public portal 


\title{
QUESTIONNAIRE SURVEY ON FACTORS INFLUENCING COMFORT WITH INDOOR ENVIRONMENTAL QUALITY IN DANISH HOUSING
}

\author{
Monika Frontczak*, Rune Vinther Andersen, Pawel Wargocki \\ International Centre for Indoor Environment and Energy, Department of Civil Engineering, \\ Technical University of Denmark, Building 402, 2800 Kgs. Lyngby, Denmark \\ *Corresponding author: frontczakmonika@gmail.com
}

\begin{abstract}
A questionnaire survey in Danish homes investigated the factors that influence occupants' comfort. The questionnaire contained questions on inhabitants' behaviour, their knowledge as regards building systems designed for controlling the indoor environment and the ways in which they achieve comfort. A total of 2499 questionnaires were sent to inhabitants of the most common types of housing in Denmark; 645 persons replied (response rate of 26\%). The results show that the main indoor environmental parameters (visual, acoustic and thermal conditions, and air quality) are considered by occupants to be the most important parameters determining comfort. Manual control of the indoor environment was indicated by the respondents as highly preferred, and only in the case of temperature did they accept both manual and automatic control. The respondents indicated that they were confident about how the systems for controlling indoor environmental quality in their homes should be used. 54\% of them reported to have had at least one problem related to the indoor environment at home. A majority of those respondents did not try to search for information on how to solve the problem. This may suggest that there is a need for increasing people's awareness regarding the consequences of a poor indoor environment on their health and for improving people's knowledge on how to ensure a good indoor climate.
\end{abstract}

\section{KEY WORDS}

comfort, occupant behaviour, control, survey, housing

\section{INTRODUCTION}

In the developed part of the world people spend almost $90 \%$ of their time indoors [1, 2]. Indoor conditions have serious implications for their health, comfort and general well-being. More than half of the time spent indoors takes place in homes. It is therefore important to identify the parameters that influence the comfort of inhabitants in their homes and to see how their behaviour may influence their comfort, especially considering that information on this subject is not extensive. For example, in the majority of Danish homes, indoor environment is to a large extent controlled manually by the building users by, e.g. opening the windows to regulate ventilation or setting the thermostat levels to regulate heating. As a consequence building occupants, whether aware of it or not, are responsible for ensuring indoor environment and through their behaviour they influence their comfort and even health.

Many studies have investigated the behaviour of people in residential buildings [3-9]. The studies have resulted in defining patterns of human behaviour in relation to window opening, use of airconditioning and control of temperature, lighting and solar shading, depending on outdoor and indoor conditions. Some of these studies recognized that it is not only physical conditions that influence the behaviour of building occupants. Andersen et al. [5] found that gender and ownership of the dwelling influenced the way in which people control the indoor environment. Guerra-Santin and Itard [9] observed that the duration for radiators to be turned on was associated with the type of thermostat, the presence of elderly people, and past residence. Brundrett [3] showed that the number 
of open windows was higher in families where a housewife stayed at home and that it increased with the size of the family. The study of Schweiker and Shukuya [7] indicated that the use of airconditioning units differed depending on the origin of a person, experience from childhood and attitude towards air-conditioning. Besides the above-mentioned factors, the behaviour of building occupants is also influenced by their knowledge of and experience with using building systems for controlling the indoor environment. Peeters et al. [10] found that building occupants did not know how to operate thermostatic radiator valves and as a result overheating often occurred in households in Belgium. Also in China it was observed that people did not understand well how the thermostatic radiator valves function and used them as they would manually controlled valves [8]. In the U.K. people had problems with controlling a heating system [11]. A study in Denmark showed that people did not feel confident in regulating heating in homes and felt that they needed more information [12]. People experience difficulties in using other systems, e.g. room air-conditioners, as shown in studies in the U.S. [13, 14]; in Japan they only used a limited number of features of the air-conditioners [15]. In contrast, Finnish occupants felt quite confident about their knowledge of heating and ventilation systems in homes [16]. The above results show that understanding how people behave indoors and how they operate the systems for controlling the indoor environment demands an in-depth knowledge which is crucial for developing systems that provide comfort for building occupants.

It is also important to understand what determines comfort for building occupants. The literature survey by Frontczak and Wargocki [17] concluded that 4 main indoor environmental parameters (thermal, visual, acoustic environment and air quality) contribute to a satisfying indoor environment; of the 4, thermal comfort was perceived by building occupants to be of greater importance for comfort compared with visual and acoustic comfort and good air quality. The literature survey also suggested that apart from indoor environmental parameters there are other factors that can influence satisfaction with the indoor air quality, among others, type of building, occupants' control over the indoor environment and outdoor climate, including season.

The objective of the present study was to understand what constitutes comfort in housing and to examine building users' preferred ways of achieving comfort. The survey also aimed at understanding how people act indoors, especially when they face indoor environmental problems, how much they know about using systems for controlling the indoor environment and where they find the information about how to deal with such problems. The study is part of a larger research programme on a user-driven innovation aiming to develop control solutions for indoor environments that maximize comfort for building occupants and enhance their quality of life. Thus the present survey is created also to gain feedback on how future solutions for controlling the indoor environment should be developed so as to secure comfort of building occupants and at the same time present to them a system which is acceptable and desirable.

\section{METHODS}

Invitations to participate in the survey were sent by regular mail to 2499 addresses in Denmark. The addresses were obtained from a national building and housing database (BBR), which includes data of all buildings in Denmark. It was aimed to gather responses of inhabitants of the most common residential buildings in Denmark. Table 1 depicts seven groups representing the most common residential buildings, depending on the type of housing (apartments in a block of flats, twin- or row houses and one-family houses) and on the ownership type (privately owned, cooperative housing association and private housing association). 357 addresses were requested to be randomly drawn from the BBR database for each housing type so that the responses would cover equally different 
types of residential building stock in Denmark. One-family houses in cooperative and private housing associations are very rare so no addresses were requested for these groups. Table 1 presents the number of addresses received from the BBR database for each group. 25 addresses (1\%) represented another housing type than requested from the BBR database. These 25 addresses belonged to one-family houses owned by a cooperative housing association or private housing association as well as privately owned farmhouses, hotel, summer houses or other residential buildings. The questionnaires were sent nevertheless to their owners and included in the analysis since it was not the purpose of the present work to discuss differences in responses between various groups of buildings but to advance our knowledge about inhabitants' behaviour and knowledge as regards building systems designed for controlling the indoor environment and factors influencing their comfort at home. Among respondents answering the invitation to fill out the questionnaire, 2 rewards of 1000 DKK (ca. €130) were drawn.

Table 1 Number of people who were invited to participate in the study and who filled out the questionnaire per housing type.

\begin{tabular}{|c|c|c|c|c|c|c|c|c|}
\hline & \multicolumn{4}{|c|}{ Invited } & \multicolumn{4}{|c|}{ Responded } \\
\hline & $\begin{array}{l}\text { Apartment } \\
\text { in a block } \\
\text { of flats }\end{array}$ & $\begin{array}{l}\text { Twin- or } \\
\text { row } \\
\text { house }\end{array}$ & $\begin{array}{l}\text { One- } \\
\text { family } \\
\text { house }\end{array}$ & Total & $\begin{array}{l}\text { Apartment in } \\
\text { a block of } \\
\text { flats }\end{array}$ & $\begin{array}{l}\text { Twin- or } \\
\text { row } \\
\text { house }\end{array}$ & $\begin{array}{l}\text { One- } \\
\text { family } \\
\text { house }\end{array}$ & Total \\
\hline Privately owned & 349 (14\%) & $\begin{array}{r}357 \\
(14 \%)\end{array}$ & $\begin{array}{r}356 \\
(14 \%)\end{array}$ & $\begin{array}{r}1062 \\
(42 \%)\end{array}$ & $82(13 \%)$ & $\begin{array}{r}125 \\
(19 \%)\end{array}$ & $\begin{array}{r}139 \\
(22 \%)\end{array}$ & $\begin{array}{r}346 \\
(54 \%)\end{array}$ \\
\hline $\begin{array}{l}\text { Cooperative } \\
\text { housing } \\
\text { association }\end{array}$ & 357 (14\%) & $\begin{array}{r}352 \\
(14 \%)\end{array}$ & $\mathrm{X}$ & $\begin{array}{r}709 \\
(28 \%)\end{array}$ & $39(6 \%)$ & $\begin{array}{r}70 \\
(11 \%)\end{array}$ & $\mathrm{X}$ & $\begin{array}{r}109 \\
(17 \%)\end{array}$ \\
\hline $\begin{array}{l}\text { Private housing } \\
\text { association }\end{array}$ & 354 (14\%) & $\begin{array}{r}349 \\
(14 \%)\end{array}$ & X & $\begin{array}{r}703 \\
(28 \%)\end{array}$ & $80(12 \%)$ & $\begin{array}{r}103 \\
(16 \%)\end{array}$ & X & $\begin{array}{r}183 \\
(28 \%)\end{array}$ \\
\hline Total & $\begin{array}{r}1060 \\
(42 \%)\end{array}$ & $\begin{array}{r}1058 \\
(42 \%)\end{array}$ & $\begin{array}{r}356 \\
(14 \%)\end{array}$ & $\begin{array}{r}2474 \\
(99 \% *)\end{array}$ & $201(31 \%)$ & $\begin{array}{r}298 \\
(46 \%)\end{array}$ & $\begin{array}{r}139 \\
(22 \%)\end{array}$ & $\begin{array}{r}638 \\
(99 \% *)\end{array}$ \\
\hline
\end{tabular}

* $1 \%$ represented other housing type than requested

A letter with the invitation to participate in the study contained a one-page description of the project and an invitation to fill out the survey online. The first reminder in the form of a postcard was sent 6 days after the first invitation letter to all 2130 non-respondents. The second reminder containing a paper-based questionnaire (only background questions and questions regarding homes) was sent 12 days after the first invitation to 1000 randomly chosen non-respondents. In total, 47 letters and postcards were returned due to wrong addresses, resulting in a final sample size of 2452 addresses. Of these, 533 persons filled out the questionnaire on-line (response rate 22\%) and 112 persons filled out the paper-based questionnaire (response rate $4 \%$ ); their responses were manually added to the database (twice to check for gross errors). The total response rate was only $26 \%$ despite 2 reminders. No non-respondent analysis was carried out.

The questions included in the questionnaire were selected in accordance with the objectives of the project, i.e. to gain inspiration for concepts of future solutions for controlling the indoor environment, which will secure comfort to building occupants and at the same time be solutions which are desired by them. The contents of the questionnaire were selected based on the results of earlier stages of the project: the literature survey [17] and field studies among 5 families [18, 19]. During field studies the families were visited at their home, workplace and kindergarten (children). They were interviewed concerning their perception and knowledge about the indoor environment, their behaviour in relation to it and the way of dealing with indoor environmental problems if any. 
The questionnaire was composed of 3 parts:

1. Background questions:

- socio-demographic questions regarding age and gender of the respondent and co-habitants, education and type of work of the respondent, total income of the family;

- questions regarding evaluation of the indoor environment, perceived importance of single environmental parameters for achieving a good indoor climate;

- questions regarding current location, i.e. where they filled in the questionnaire (home, outdoors, office, etc.);

- open questions about a location where respondents feel comfortable and what factors contribute to comfort at this location.

2. Questions regarding home which addressed the following:

- behaviour in relation to window opening, adjusting heating and turning the lights on;

- preference for ways of controlling the indoor environment;

- self-estimated level of knowledge about how to use heating and ventilation systems optimally and extent of benefiting from receiving advice on how their homes should be ventilated, cleaned and heated;

- indoor environmental quality problems that respondents had and the methods used to solve them as well as how knowledge about the solution of problems was found;

3. Questions regarding workplace, addressing the same items as under point (2) above. This part of the questionnaire was presented only to those who filled out the questionnaire online and answered that they work in an office or children's institution (nursery, kindergarten, school, etc.). Only 195 respondents met these requirements resulting in a very low response rate, as indicated below.

The present paper reports results for background questions (part 1) and home environment (part 2). No analysis of responses regarding the work environment are included, one of the reasons being a very low response rate regarding workplace $(6 \%)$.

Two questions were open type; the respondents described a location where they felt comfortable and identified the factors that contributed to comfort. Other questions were answered in one of the four following ways:

(A) on a continuous scale: Acceptability of indoor environmental parameters was assessed using continuous scales ranging from 'clearly acceptable' (coded as 1 in the analysis) to 'clearly unacceptable' (coded as -1); the scales are presented in Standard EN15251 [20], annex H. The question about acceptability of the indoor environment was formulated in the following way: "How do you assess thermal environment/ air quality/ sound quality/ light quality/ quality of indoor environment at the moment?";

(B) on a 'yes' and 'no' scale with additional 'I do not know' answer. Respondents could choose only one answer to each question;

(C) on a 3- to 6-point scale which e.g. evaluated the degree of importance of different parameters or frequency of different behaviours. Additionally in these questions respondents could choose 'I do not know' answer. Respondents could choose only one answer to each question;

(D) using a list of possible answers e.g. describing possible indoor environmental quality problems or reasons for different behaviours. Apart from background questions respondents could also choose answer 'I do not know' or add their own answer in the empty field if their reply was not mentioned in the list of possible answers. Typically respondents could choose more than one answer. 
At first multivariate linear regression model was fitted to responses evaluating acceptability of individual indoor environmental conditions and an overall acceptability with the indoor environment. However, the assumptions of constant variance of error term and normal distribution of residuals were not satisfied even after transforming the overall acceptability with the indoor environment (dependent variable) with reciprocal squared or exponential transformations. Consequently, a different statistical analysis was used being a non-parametric Spearman correlation evaluating the relation between acceptability of the overall indoor environment and acceptability of air quality and thermal, visual and acoustic environment.

Statistical significance of differences in responses of different respondents was tested by Wilcoxon rank sum test (known also as Mann-Whitney test) or $\chi^{2}$ test [21]. The analysis was carried out in the statistical software $\mathrm{R}$ [22]. The results were considered statistically significant when $\mathrm{p}<0.05$, 2 tailed.

\section{RESULTS AND DISCUSSION}

\section{Response rate}

Since the response rate was only $26 \%$ and a non-respondent analysis was not performed, the responses cannot be considered as representative for the Danish population due to potential of selection bias. Nevertheless, they carry important information regarding comfort and behaviour in Danish housing of which data is meagre. The lowest response rate was among people living in the apartments and in cooperative housing association (Table 1). The respondents had a higher education status than an average Dane. In our sample there was also an underrepresentation of people younger than 52 years and an overrepresentation of people aged 52 years old and older as compared to the Danish adult population as of April 2011 (http://www.statistikbanken.dk/statbank5a/default.asp?w=1280). This skewness could be caused by the fact that most of the paper-based questionnaires (79\%) were filled out by respondents older than 52 years, which accounts for $72 \%$ of all respondents.

The influence of the overrepresentation of respondents older than 52 years old on the results of the study was verified by performing additional analysis. Respondents were divided into 2 groups: those younger than 52 years old and those aged 52 years and over (10 respondents were disregarded from additional analysis because they did not indicate their age). Statistical analysis showed that the differences between respondents younger and older than 52 years old are small, if any, which suggests that the overrepresentation of people older than 52 years in our sample has a small impact on the overall study results.

\section{Comfort}

Figure 1 shows acceptability levels with indoor environmental parameters (air quality, thermal, visual, acoustic and overall environment) as assessed by the respondents. Respondents were generally satisfied with the overall indoor environment. The highest mean acceptability was observed for the air quality and the lowest for the thermal environment. Using the relationship of Gunnarsen and Fanger [23] the observed levels of acceptability correspond generally to less than $22 \%$ of dissatisfied. 


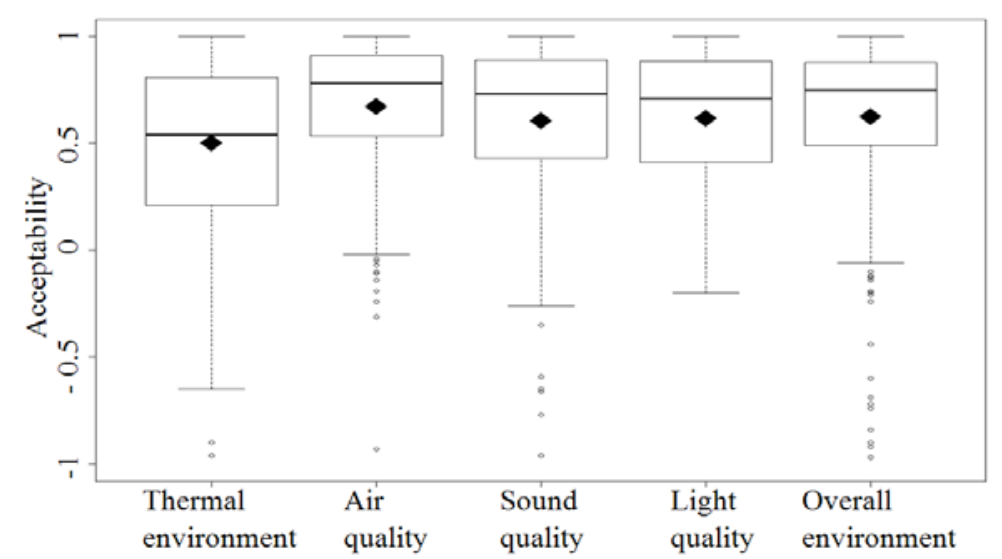

Figure 1 Box plots for acceptability with indoor environmental parameters assessed in the questionnaire. Filled squares represent mean values. Thick lines represent median values. The extremes of boxes represent $25^{\text {th }}$ and $75^{\text {th }}$ percentile.

To understand which parameters determine building occupants' comfort, acceptability of the overall indoor environment was correlated with acceptability of all 4 main indoor environmental parameters (Table 2). The correlations were based on between 564 and 569 responses due to the fact that some of the respondents did not evaluate all environmental parameters and only evaluations made at home were included. All correlations were significant and positive, indicating that an increase of acceptability with thermal, visual, acoustic environment or air quality will result in an increase of acceptability of the overall indoor environment; all parameters contributed thus to comfort as expected [17]. Correlations have the same range of magnitude, indicating that all 4 main environmental parameters are equally important for the assessments of the overall indoor environment and contribute equally much to the overall acceptability if only their acceptability levels are similar to the ones reported here (Figure 1). Similar results were obtained when respondents were asked to compare pairwise which indoor environmental parameters were more important. Most respondents answered that the indoor environmental parameters were equally important (Table 3). The results differ slightly from recently published data collected in buildings in many different climate zones, which showed that the thermal environment is ranked to have slightly higher importance for overall comfort than acoustic and visual environment and air quality [17] and that noise conditions were more important for overall comfort than temperature, light and air quality [24]. It is not possible to examine whether the results disagree due to climatic or other differences.

Table 2 Spearman correlation coefficients between acceptability of the overall indoor environment and acceptability of thermal, visual and acoustic environment and air quality.

\begin{tabular}{|l|l|}
\hline Parameter & Coefficient \\
\hline Air quality & $0.64^{*}$ \\
\hline Visual & $0.52^{*}$ \\
\hline Acoustic & $0.52^{*}$ \\
\hline Thermal & $0.48^{*}$ \\
\hline
\end{tabular}

$* \mathrm{p}<0.001$ (2-tailed test) 
Table 3 Summary of responses to the question 'What in your opinion is more important for a good indoor environment?'.

\begin{tabular}{|l|l|r|r|r|r|}
\hline Parameter A & Parameter B & $\begin{array}{l}\text { A more } \\
\text { important than } \\
\text { B }\end{array}$ & $\begin{array}{l}\text { A and B } \\
\text { equally } \\
\text { important }\end{array}$ & $\begin{array}{l}\text { B more } \\
\text { important than } \\
\text { A }\end{array}$ & No answer* \\
\hline Temperature & Air quality & $18 \%$ & $59 \%$ & $13 \%$ & $10 \%$ \\
\hline Temperature & Lighting & $32 \%$ & $45 \%$ & $12 \%$ & $11 \%$ \\
\hline Temperature & Acoustics & $27 \%$ & $42 \%$ & $18 \%$ & $13 \%$ \\
\hline Air quality & Lighting & $32 \%$ & $44 \%$ & $11 \%$ & $13 \%$ \\
\hline Air quality & Acoustics & $30 \%$ & $43 \%$ & $14 \%$ & $13 \%$ \\
\hline Lighting & Acoustics & $23 \%$ & $45 \%$ & $17 \%$ & $15 \%$ \\
\hline
\end{tabular}

* Category 'No answer' includes both responses 'I do not know' and respondents who did not provide any answer.

305 respondents (47\% of all respondents) indicated a location where they feel comfortable. Home was mentioned by most of the respondents (58\%); they also felt comfortable outdoors (9\%), in a summer house (7\%), at holidays' destinations (4\%) and in the office (4\%). They described in their own words which factors contribute to comfort. The 10 most frequently mentioned factors are presented in Table 4. Indoor environmental parameters (light, temperature, air quality and noise level) were mentioned as parameters contributing the most to comfort, together with peace and silence, contact with the nature and view. This agrees with previous studies [24-27] which showed that also other factors not related to the indoor environment influence the perception of comfort. Considering the high importance of the indoor environment for comfort, it is surprising that in many Danish offices, providing a good indoor environment is not given high priority [28].

Table 4 Ten most frequently used words in 305 descriptions of factors contributing to comfort.

\begin{tabular}{|l|r|}
\hline Factor & Percentage of all responses \\
\hline light, sun & $46 \%$ \\
\hline temperature, warmth & $35 \%$ \\
\hline fresh/clean air, smell & $21 \%$ \\
\hline sound, noise & $16 \%$ \\
\hline peace, silence & $15 \%$ \\
\hline nature & $15 \%$ \\
\hline view & $14 \%$ \\
\hline size of room & $9 \%$ \\
\hline family and friends & $8 \%$ \\
\hline room interior, style, furniture & $8 \%$ \\
\hline
\end{tabular}

\section{Classification of indoor environment based on comfort}

Standard EN15251 [20] recommends overall classification of the indoor environment based on evaluation of indoor environmental parameters separately. It suggests an approach to classify and certify the buildings using the levels of individual environmental parameters (Appendix I [20]) but it does not provide any information on how to combine different environmental parameters into one index which can be used to classify the indoor environmental conditions in the building. The present analysis (Table 2) suggests that if acceptability of thermal, acoustic, visual conditions and air quality are of a similar magnitude corresponding to less than $30 \%$ dissatisfied, the acceptability 
of the overall environment can be approximated by averaging acceptability of these individual factors. Present results can thus be used to classify the indoor environment but only in buildings meeting at least category III in the Standard EN15251 [20]. Further studies should be used to examine how the individual parameters of indoor environment influence overall acceptability of indoor environment in case any of them cause more than 30\% dissatisfied.

\section{Windows opening vs. mechanical ventilation system}

Respondents valued natural ventilation highly and it was very important for them that they could open a window in their home (Table 5). They indicated that the possibility to open the windows gave them a chance to take care of their own and their family's health and to air their homes. For many respondents it was not important that their homes are aired out with mechanical ventilation (Table 5). However, supplying fresh air by mechanical ventilation was valued slightly higher by respondents who had mechanical ventilation than those without mechanical ventilation at home (Table 5); the difference being statistically significant $(\mathrm{p}<0.001)$. It is interesting to observe that $43 \%$ of respondents with mechanical ventilation expressed that supplying fresh air from mechanical ventilation was not important for them and they valued highly the possibility of window opening. These results may be a consequence of a strong preference for manual control over the indoor environment as discussed later. They agree with the preference for natural ventilation also observed in the previous studies [4, 15], which showed that Japanese people believed that natural cooling (window opening) was much better in respect to their health than air-conditioning. The results show also that respondents may associate fresh air with window opening rather than with mechanical ventilation, despite the increasing evidence of negative effects of outdoor air pollution on health, especially in cities [29], and despite increasing evidence that the installation of a mechanical ventilation system in homes reduces health problems especially related to asthma and allergy [30]. The majority of respondents live in houses, which in Denmark are generally situated in suburbs and rural areas outside the city centres and away from heavy traffic and pollution; we did not, however, ask the survey participants about their outdoor air quality, which is generally considered to be good in Denmark except for a few downtown areas.

No significant differences were found in the frequency of window opening in summer and winter between respondents with and without mechanical ventilation. A previous qualitative study among 29 families showed that window opening was embedded in practices of everyday life such as morning routines or cleaning [31]. It was a way of expressing love and care for the family and the house and connecting to nature. Social aspects and routine behaviours associated with window opening may explain why the respondents valued the possibility of window opening.

Table 5 Summary of results showing the importance of being able to open windows or having mechanical ventilation system at home.

\begin{tabular}{|l|r|r|r|r|r|}
\hline & $\begin{array}{l}\text { Very } \\
\text { important }\end{array}$ & Important & $\begin{array}{l}\text { Not very } \\
\text { important }\end{array}$ & $\begin{array}{l}\text { Not at all } \\
\text { important }\end{array}$ & $\begin{array}{l}\text { No } \\
\text { answer* }\end{array}$ \\
\hline $\begin{array}{l}\text { How important is it to have the } \\
\text { possibility of opening a window? }\end{array}$ & $86 \%$ & $6 \%$ & $1 \%$ & $0 \%$ & $7 \%$ \\
\hline $\begin{array}{l}\text { How important is it to always have } \\
\text { fresh air supplied by a mechanical } \\
\text { ventilation system? All respondents }\end{array}$ & $10 \%$ & $7 \%$ & $21 \%$ & $27 \%$ & $35 \%$ \\
\hline $\begin{array}{l}\text { How important is it to always have } \\
\text { fresh air supplied by a mechanical }\end{array}$ & $5 \%$ & $5 \%$ & $21 \%$ & $34 \%$ & $35 \%$ \\
\hline
\end{tabular}




\begin{tabular}{|l|r|r|r|r|r|}
\hline $\begin{array}{l}\text { ventilation system? Respondents } \\
\text { without mechanical ventilation system } \\
\text { at home (N=439) }\end{array}$ & & & & & \\
\hline $\begin{array}{l}\text { How important is it to always have } \\
\text { fresh air supplied by a mechanical } \\
\text { ventilation system? Respondents with } \\
\text { mechanical ventilation system at home } \\
(\mathrm{N}=145)\end{array}$ & & & & & \\
\hline
\end{tabular}

* Category 'No answer' includes both responses 'I do not know' and respondents who did not provide any answer.

\section{Dealing with indoor environmental quality problems}

$54 \%$ of respondents reported to have at least one indoor environmental quality problem at home. Most of the problems were related to temperature. Respondents were disturbed by either cold floors (22\% of all respondents) and/or too high temperature in the summer (20\%). They also experienced condensation on windows (16\%), too low temperature in winter $(14 \%)$, noise from outside or neighbours (14\%) and draught (12\%). Very few reported to have mould (5\%) or complained about too little daylight (4\%).

It was investigated whether the way people arrange their homes may influence the occurrence of indoor environmental problems. Respondents were asked to evaluate the importance of different factors while arranging their homes. Table 6 shows that creating a cosy atmosphere, consideration of the purpose of the room and luminous conditions, especially daylight, had the highest influence on the arrangement of homes. Noise, draught and temperature conditions were considered to be much less important. It is interesting to observe that while arranging their homes, respondents paid least attention to factors that were later a reason for indoor environmental problems.

Table 6 Ranking of importance of different factors considered when respondents were arranging their homes based on responses from between 537 and 588 respondents (some of the respondents did not evaluate all the parameters).

\begin{tabular}{|l|r|}
\hline Factor & Mean vote* \\
\hline Creating cosy atmosphere & 2.19 \\
\hline Purpose of the room & 2.10 \\
\hline Daylight conditions & 1.94 \\
\hline Privacy & 1.83 \\
\hline Creating practical working conditions & 1.83 \\
\hline Colours & 1.82 \\
\hline Artificial lighting conditions & 1.70 \\
\hline Price & 1.67 \\
\hline View & 1.63 \\
\hline Noise & 1.62 \\
\hline Draught & 1.61 \\
\hline Thermal conditions & 1.59 \\
\hline Creating / showing your style & 1.47 \\
\hline $\begin{array}{l}\text { Location of heating sources (radiators, ventilation system, floor } \\
\text { heating) }\end{array}$ & 1.39 \\
\hline
\end{tabular}

* 3 means very big influence; 0 means no influence. 
Among respondents who reported to have indoor environmental quality problems, more than half of them did not try to find information on how to solve the problem which they faced (Table 7, row A), mostly because they believed that the problem was not serious enough to act upon (Table 8). Among those who tried to find information, the most common source of information was the Internet (Table 9). Respondents avoided solving an indoor environmental quality problem due to financial reasons (30\%) and because it was believed that the problem was not serious enough to act upon (29\%). However, the behaviour of respondents depended on the kind of problem they faced. Among those who observed mould at their home, a rather serious problem, $65 \%$ of them tried to find information on how to solve this problem. They mainly searched for information on the Internet (45\% of respondents) or contacted their family and friends (27\%). Only $14 \%$ consulted an expert in the field. The results suggest that mild problems are likely not to lead to any action and therefore it is of utmost importance that some guidance to the occupants is given because if not handled immediately it can lead to much more serious problems. One way of dealing with it is an apparatus informing the building users what to do.

Table 7 Distribution of responses regarding respondents' knowledge in relation to using ventilation and heating systems and their perceived need for more information on this matter.

\begin{tabular}{|l|l|l|l|l|}
\hline $\begin{array}{l}\text { Row } \\
\text { nr }\end{array}$ & Question & Yes & No & $\begin{array}{l}\text { No } \\
\text { answer* }\end{array}$ \\
\hline A & $\begin{array}{l}\text { Did you try to find information about how to solve an indoor } \\
\text { environmental problem you face? (N=342; only respondents } \\
\text { who indicated earlier that they had at least one indoor } \\
\text { environmental quality problem were asked) }\end{array}$ & $32 \%$ & $59 \%$ & $9 \%$ \\
\hline B & $\begin{array}{l}\text { Do you think you know enough to take good care of your } \\
\text { home and use ventilation and heating systems properly? All } \\
\text { respondents }\end{array}$ & $74 \%$ & $12 \%$ & $14 \%$ \\
\hline C & $\begin{array}{l}\text { Do you think you would profit from being given advice on } \\
\text { your behaviour in relation to ventilating, cleaning and } \\
\text { heating? All respondents }\end{array}$ & $36 \%$ & $50 \%$ & $14 \%$ \\
\hline C1 & $\begin{array}{l}\text { Do you think you would profit from being given advice on } \\
\text { your behaviour in relation to ventilating, cleaning and } \\
\text { heating? (N=347; only those respondents who indicated that } \\
\text { they have at least one indoor environmental quality } \\
\text { problem) }\end{array}$ & $48 \%$ & $46 \%$ & $6 \%$ \\
\hline C2 & $\begin{array}{l}\text { Do you think you would profit from being given advice on } \\
\text { your behaviour in relation to ventilating, cleaning and } \\
\text { heating? (N=238; only those respondents who indicated that } \\
\text { they do not have indoor environmental quality problems) }\end{array}$ & $26 \%$ & $65 \%$ & $9 \%$ \\
\hline D & $\begin{array}{l}\text { Would you use an apparatus which could guide you on how } \\
\text { to secure a good indoor climate while using as little energy } \\
\text { as possible if such an apparatus existed? }\end{array}$ & $46 \%$ & $24 \%$ & $30 \%$ \\
\hline
\end{tabular}

* Category 'No answer' includes both responses 'I do not know' and respondents who did not provide any answer. 
Table 8 Distribution of responses regarding reasons why respondents did not try to find information on how to solve the problems which they faced $(\mathrm{N}=201)$.

\begin{tabular}{|l|l|}
\hline Answer & Percentage of respondents \\
\hline The problem was not serious enough to act & $51 \%$ \\
\hline $\begin{array}{l}\text { I already knew enough about the solution and I did not need additional } \\
\text { information }\end{array}$ & $20 \%$ \\
\hline It is not my responsibility & $7 \%$ \\
\hline I did not know where to find relevant information & $5 \%$ \\
\hline
\end{tabular}

Table 9 Distribution of responses regarding the source of information about how to solve the problems which respondents faced $(\mathrm{N}=111)$.

\begin{tabular}{|l|l|}
\hline Answer & Percentage of respondents \\
\hline I searched on the Internet & $41 \%$ \\
\hline I contacted experts in the field & $30 \%$ \\
\hline I asked my family and/or friends for information & $24 \%$ \\
\hline
\end{tabular}

The results show that respondents judged mainly on their own how serious the problem was without contacting the experts in the field. Regular inspections of homes with subsequent mandatory repairs would probably ensure that indoor environment is at acceptable level, but there is quite meagre evidence of their effectiveness, although analogous regular car checks are quite successful. Regular inspections of HVAC systems in public buildings are mandatory in Sweden [32], while in Portugal regular energy audits imposed by the Energy Performance of Buildings Directive (EPBD) [33] are accompanied by the measurements of indoor air quality which can identify potential problems. A diagnostic tool, which will help to evaluate the seriousness of indoor environmental problems, can also be developed. The results indicate that an internet-based tool might be effective since respondents indicated the Internet as the most common source of information. This tool should provide an estimated cost of solving the problem as well as health- and building-related consequences of not solving the problem, to help people make an informed decision as to whether or not the problem should be solved. In Denmark there are already some websites where different issues of the indoor environment are described and people can find information and advice, but we do not know on which basis people judge whether the information is credible or not. A big challenge is to reach people who ignore the problems and fail to look for more information. Among them, 58\% indicated that they had little or no knowledge as to whether the problem had any serious consequences on their health or building conditions. These people may be addressed by educational campaigns. A survey among Danish citizens showed that increased knowledge may lead to change of behaviour (Zapera [34]). In Zapera's survey, around $40 \%$ of respondents indicated that they would open a window more often in winter and clean more often at home if they knew that it was good for their families' health and wellbeing. Over 30\% of respondents would open a window more often in winter if they knew that there are harmful compounds in the indoor air and if they knew that it would improve indoor environmental quality. Monetary consequences of ignorance can also create incentives. Information about the indoor environment may also be described in the daily press and magazines in an easily understandable way for laymen. In this way people will be addressed without actively looking for information leading to increased awareness about ensuring a good indoor environment and to positive change of behaviour. 


\section{Control over the indoor environment}

A vast majority of respondents preferred manual control over artificial light, window opening and solar shading (Figure 2). They were more positive regarding automatic control or a combination of manual and automatic control in relation to control of temperature in their homes. In the majority of Danish homes indoor environmental conditions are controlled manually apart from semi-automatic control of temperature by means of thermostatic radiator valves. In some homes there is also mechanical ventilation which can be considered as an automatic means to control the indoor climate. To examine whether the preference for manual control is caused by lack of it, preferred control was compared in homes with and without a mechanical ventilation system. No difference was found except for higher preference for non-manual control over artificial light among respondents with mechanical ventilation $(p=0.014)$. The reason for these results could be that many of the respondents could be unaware of the fact that they have automatic control of the indoor environment or that even though the automatic control is present in their homes they still prefer to manually control or override it.

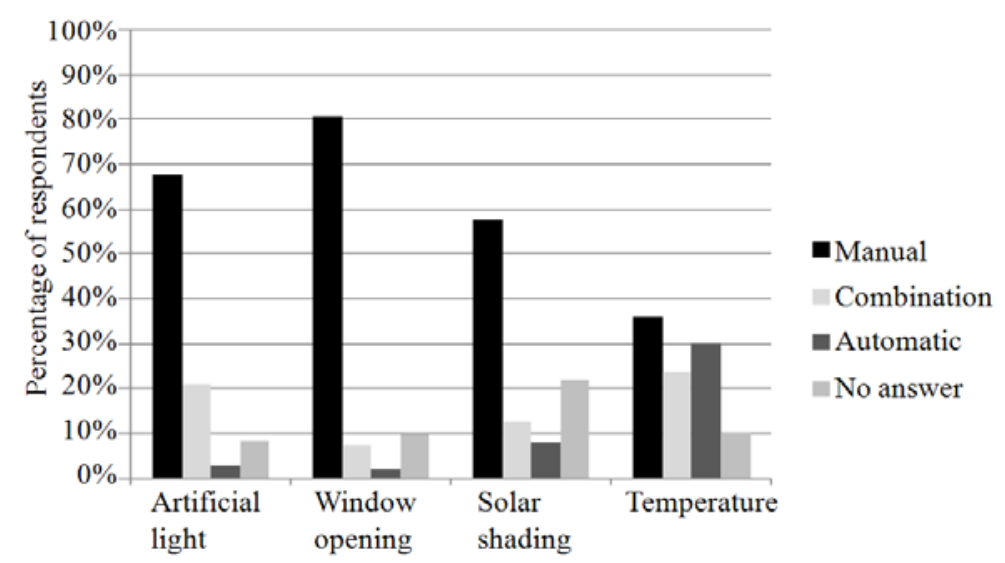

Figure 2 Percentage of respondents preferring a different type of control of indoor environmental parameters. Category 'No answer' includes both responses 'I do not know' and respondents who did not provide any answer.

$70 \%$ of respondents indicated that they were at least a bit aware how their behaviour influenced energy use and indoor environmental quality and only 5\% of respondents knew nothing or almost nothing about it. In the opinion of $75 \%$ of respondents it was easy to understand how the shading, ventilation and heating systems work and how to use them optimally. Respondents expressed belief that they had enough knowledge to use the systems for controlling the indoor environment correctly and to take good care of their home (Table 7, row B). Otherwise, they would contact a professional (technician or janitor; $48 \%$ of all respondents), ask their family and friends for advice (40\%) or look for information on the Internet (33\%). Only $2 \%$ of respondents did not know who to contact or would not do anything, and the majority of them were over 52 years old.

Several questions were used to find out what is the preferred means of information about achieving good indoor environment. Most of the respondents indicated that they did not need any advice on their behaviour in relation to ventilating, cleaning and heating (Table 7, row C). Among respondents who faced indoor environmental quality problems there were significantly $(\mathrm{p}<0.01)$ more respondents who indicated that they would profit from being given such advice, compared to the group of respondents who did not face any indoor environmental quality problem (Table 7, row C1 and C2). If the advice would be accepted, respondents would rather prefer it in a form of an 
apparatus guiding them on how to obtain a good indoor climate while using as little energy as possible (Table 7, row D). The question about an apparatus was hypothetical and did not specify the working principle of the apparatus. It aimed at investigating if people would prefer an advice from an instrument rather than a person. An apparatus could also provide a continuous feedback to the occupants, potentially avoiding serious problems in the future due to inadequate housing conditions. The vast majority of those who would use guidance from an apparatus believed that it could help them being more energy conscious (60\% of respondents) and it would improve their indoor environmental quality (57\% of respondents). The most common reason for not being willing to use such guidance was that respondents felt that they knew how to ensure a good indoor environment in an effective way and did not need any more guidelines regarding indoor air quality (65\%). They also did not want their behaviour to be controlled by a special apparatus (14\%) and would forget to look at an apparatus (13\%). The results are in accordance with a general negative attitude towards automatic control of indoor environment discussed earlier and high confidence in own abilities to deal with problems. Also in studies of Karjalainen [16] and Price and Sherman [35] people felt quite confident regarding their knowledge on how a ventilation system works and how to operate it properly. However, Price and Sherman [35] concluded that respondents were not familiar enough with mechanical ventilation systems to meaningfully respond to questions about them. This to some extent agrees with the other studies which showed that people lack understanding of how to use systems properly for controlling the indoor environment and experience problems when operating them [8, 10-15].

\section{Potential solutions for controlling the indoor environment}

Two solutions for controlling the indoor environment can be considered as a result of the present survey:

- automatic control guaranteeing minimum acceptable conditions with the possibility of manual adjustment (override) of conditions to occupants' needs;

- manual control by building occupants.

In the former solution, the automatic system can be designed to ensure the minimum requirements for an acceptable indoor environment, and the occupants can adjust the indoor environment to their needs as required. In the latter solution, the building occupants are fully responsible for ensuring a good indoor environment. However, the relevant question is whether the occupants will always act when the situation arises. In the study of Price and Sherman [35] in the U.S. nearly 50\% of respondents indicated that they sometimes failed to use the bathroom fan even when conditions clearly required it, most often because they simply did not think of it. In such a situation, a basic automatic ventilation of the bathroom (e.g., a fan that turns on when the light is turned on or humidity is too high) could be an appropriate solution. Another solution is a system that warns when people should act, or a system that continuously visualizes whether indoor environmental quality conditions are good or poor. An attempt to create such a system was made by Jaffari and Matthews [18] who suggested an artificial plant that wilts at high $\mathrm{CO}_{2}$ levels while low $\mathrm{CO}_{2}$ levels make it rise back to the upright position. No data describing the practical use of such a plant is available. Broer [36] constructed a lamp that represents the levels of temperature, humidity, sound, light and $\mathrm{CO}_{2}$ by means of light; he placed it in the home of one family for 9 days and the idea to visualize the indoor environment through lights seemed appealing to the family. Kim and Paulos [37] designed a tool for continuous graphical visualization of indoor air quality (based on measurements of particles below 0.5 microns); they placed it in 5 homes for 2 weeks and observed that it had a positive impact on willingness to take action to improve the indoor environment. In the present study, respondents were asked how much they are willing to pay for an apparatus that 
would guide them on how to ensure a good indoor climate while using as little energy as possible. They would pay on average $€ 230$ (range between $€ 0$ and $€ 2600$ ).To ensure that people's interest towards indoor air quality is attracted, it may be necessary to relate to some values that are important such as e.g. energy saving and financial consequences related not only to energy but also to health consequences associated with lost days from work, medical costs etc. [38].

\section{CONCLUSIONS}

Indoor environmental parameters were acknowledged by the respondents to influence comfort. Their responses suggest that acceptability of overall indoor environment can be approximated by averaging acceptability of thermal, visual and acoustic conditions and air quality but only at the acceptability levels which are reported in the present paper. Low response rate and lack of representativeness indicates the need for validating the present results.

Manual control of the indoor environment was preferred by the respondents compared with automatic control except for control of temperature where both manual and automatic control was accepted.

Respondents associated natural ventilation (window opening) and not mechanical ventilation systems with fresh air supply.

Respondents indicated that they were aware of how their behaviour influenced indoor environmental quality. They also felt confident in using the systems for controlling the indoor environment in their homes.

Most respondents who had a problem related to the indoor environment did not try to find information on how to solve it because they considered that it was not serious.

Consequently, increasing people's awareness about the consequences of poor indoor environmental quality on their health and the knowledge about how to ensure a good indoor climate would be needed.

\section{ACKNOWLEDGEMENTS}

This study was performed as a part of the project "Indoor Climate and Quality of Life" granted by the Danish Enterprise and Construction Authority (EBST) in the programme for user-driven innovation in the period 2008-2011, grant no. 07/08368. It was also partially supported by the International Centre for Indoor Environment and Energy (ICIEE) established at the Technical University of Denmark, Department of Civil Engineering. The authors are grateful to the members of the project for providing feedback on the content of the questionnaire (Karsten Andersen and Peter Foldbjerg from Velux, Jannick Karsten Roth and Thomas Berend Nielsen from WindowMaster, Jesper Pedersen, Jacob Buur, Jared Donovan and Svenja Jaffari from University of Southern Denmark, Susanne Hoejholt from Saint-Gobain Isover and Lis Jacobsen from Nilan). Thanks are due to all families who responded to the questionnaire.

\section{REFERENCES}

[1] Leech JA, Wilby K, McMullen E, Laporte K. The Canadian human activity pattern survey: Report of methods and population surveyed. Chronic Dis Can 1997;17(3): 118.

[2] Klepeis NE, Nelson WC, Ott WR, Robinson JP, Tsang AM, Switzer P, Behar JV, Hern SC, Engelmann WH. The national human activity pattern survey (NHAPS): A resource for assessing exposure to environmental pollutants. J Expo Anal Environ Epidemiol 2001;11(3): 231-252.

[3] Brundrett GW. Ventilation: A behavioural approach. Energy Res 1977;1: 289-298.

[4] Iwashita G, Akasaka H. The effects of human behavior on natural ventilation rate and indoor air environment in summer-a field study in southern Japan. Energy Build 1997;25(3): 195-205. 
[5] Andersen RV, Toftum J, Andersen KK, Olesen BW. Survey of occupant behaviour and control of indoor environment in Danish dwellings. Energy Build 2009;41(1): 11-16.

[6] Bae C, Chun C. Research on seasonal indoor thermal environment and residents' control behavior of cooling and heating systems in Korea. Build Environ 2009;44(11): 2300-2307.

[7] Schweiker M, Shukuya M. Comparison of theoretical and statistical models of air-conditioningunit usage behaviour in a residential setting under Japanese climatic conditions. Build Environ 2009;44(10): 2137-2149.

[8] $\mathrm{Xu} \mathrm{B}, \mathrm{Fu} \mathrm{L}$, Di H. Field investigation on consumer behavior and hydraulic performance of a district heating system in Tianjin, China. Build Environ 2009;44(2): 249-259.

[9] Guerra-Santin O, Itard L. Occupants' behaviour: Determinants and effects on residential heating consumption. Build Res Inf 2010;38(3): 318-338.

[10] Peeters L, Van der Veken J, Hens H, Helsen L, D'haeseleer W. Control of heating systems in residential buildings: Current practice. Energy Build 2008;40(8): 1446-1455.

[11] Gill ZM, Tierney MJ, Pegg IM, Allan N. Low-energy dwellings: The contribution of behaviours to actual performance. Build Res Inf 2010;38(5): 491-508.

[12] Gram-Hanssen K. Residential heat comfort practices: Understanding users. Build Res Inf 2010;38(2): 175-186.

[13] Kempton W, Feuermann D, McGarity AE. I always turn it on super: User decisions about when and how to operate room air conditioners. Energy Build 1992;18(3-4): 177-191.

[14] Lutzenhiser L. A question of control: Alternative patterns of room air-conditioner use. Energy Build 1992;18(3-4): 193-200.

[15] Fujii H, Lutzenhiser L. Japanese residential air-conditioning: Natural cooling and intelligent systems. Energy Build 1992;18(3-4): 221-233.

[16] Karjalainen S. Thermal comfort and use of thermostats in Finnish homes and offices. Build Environ 2009;44(6): 1237-1245.

[17] Frontczak M, Wargocki P. Literature survey on how different factors influence human comfort in indoor environments. Build Environ 2011;46(4): 922-937.

[18] Jaffari SD, Matthews B. From occupying to inhabiting-a change in conceptualising comfort. Proceedings of beyond Kyoto: Addressing the challenges of climate change - science meets industry, policy and public, Aarhus, Denmark 2009.

[19] Jaffari SD. Re-constructing the comfort zone. J Green Build 2010;4(4): 134-147.

[20] EN15251. Indoor environmental input parameters for design and assessment of energy performance of buildings addressing indoor air quality, thermal environment, lighting and acoustics. Brussels. European committee for standardization. 2007.

[21] Siegel S. Nonparametric statistics for the behavioral sciences. McGraw-Hill Book Company; 1956.

[22] R Development Core Team. R: A language and environment for statistical computing. $\mathrm{R}$ Foundation for Statistical Computing 2009;Vienna, Austria; http://www.R-project.org.

[23] Gunnarsen L, Fanger PO. Adaptation to indoor air pollution. Environ Int 1992;18(1): 43-54.

[24] Frontczak M, Schiavon S, Goins J, Arens E, Zhang H, Wargocki P. Quantitative relationships between occupant satisfaction and satisfaction aspects of indoor environmental quality and building design. Indoor Air, 2011. doi:10.1111/j.1600-0668.2011.00745.x.

[25] Veitch JA, Charles KE, Farley KMJ, Newsham GR. A model of satisfaction with open-plan office conditions: COPE field findings. J Environ Psychol 2007;27(3): 177-189.

[26] Schakib-Ekbatan K, Wagner A, Lussac C. Occupant satisfaction as an indicator for the sociocultural dimension of sustainable office buildings - development of an overall building index. Proceedings of conference: Adapting to change: New thinking on comfort, Windsor, U.K. 2010. 
[27] Bluyssen PM, Aries M, van Dommelen P. Comfort of workers in office buildings: The European HOPE project. Build Environ 2011;46(1): 280-288.

[28] Camfil F. Danskerne plages af dårligt indeklima på jobbet; 2011.

[29] Brunekreef B, Holgate ST. Air pollution and health. Lancet 2002;360(9341): 1233-1242.

[30] Wargocki P, Sundell J, Bischof W, Brundrett G, Fanger PO, Gyntelberg F, Hanssen SO, Harrison P, Pickering A, Seppänen O, Wouters P. Ventilation and health in nonindustrial indoor environments: Report from a European multidisciplinary scientific consensus meeting (EUROVEN). Indoor Air 2002;12(2): 113-128.

[31] Hauge B. The significance of fresh air from outside: Getting to know the world through air. Proceedings of the 12th International Conference on Indoor Air Quality and Climate, Austin, TX, USA 2011: paper no. 282.

[32] Regelsamling för funktionskontroll av ventilationssystem, OVK. Karlskrona: Boverket; 2009. [33] Directive 2002/91/EC of the European Parliament and of the Council of 16 December 2002 on the energy performance of buildings. Official Journal of the European Communities 2003.

[34] Zapera rapport. Report No.: DK2007-765; 2007.

[35] Price PN, Sherman MH. Ventilation behavior and household characteristics in new California houses. Report No.: LBNL 59620. Ernest Orlando Lawrence Berkeley National Laboratory; 2006; http://escholarship.org/uc/item/8gx9v5fb.

[36] Boer L. Participatory provocations?. Proceedings of participatory innovation conference 2011, Sonderborg, Denmark 2011: 21-6.

[37] Kim S, Paulos E. inAir: Measuring and visualizing indoor air quality. Proceedings of the 11th International Conference on Ubiquitous Computing, Orlando, USA 2009: 81-4.

[38] Wargocki P. Productivity and health benefits. Encyclopedia of Environmental Health 2011; In press. 